\title{
The Effect of Various Total Nitrogen (Total-N) Concentrations in Hydroponic Nutrient on The Growth of Kailan Crop (Brassica oleraceae $\mathbf{L}$.)
}

\author{
Budy Frasetya ${ }^{1}$, Kundang Harisman ${ }^{2}$, Adham Gumilang Saputra ${ }^{3}$, Adjat Sudrajat ${ }^{4}$ \\ \{budyftq1682@gmail.com ${ }^{1}$, kundangharisman@yahoo.com², adhamgumilang@gmail.com $\left.{ }^{3}\right\}$ \\ Faculty of Science and Technology, UIN Sunan Gunung Djati Bandung ${ }^{1}$
}

\begin{abstract}
The total nitrogen concentrations (Total-N) in hydroponic nutrient affects nutrient uptake efficiency and crop growth. This research is aim to formula efficient Total Nitrogen on the hydroponic nutrient of kailan or kale crop. This research was conducted from January to February at Universitas Padjadjaran Greenhouse Jatinangor, Sumedang West Java $700 \mathrm{~m}$ above sea level. This research used an experimental method, and the experimental design was used Completely Randomized Design with seven treatments, i.e., 190, 210, 230, 250, 270, 290, $310 \mathrm{ppm}$ and four replications. The parameter observed in this research Parameter, i.e. Main parameter (crop height, leaf area, crop dry weight, shoot-root ratio, and crop fresh weight) and secondary observation ( temperature, greenhouse humidity, and $\mathrm{pH}$ nutrient). The data collected from the main observation and secondary observation than analyzed with variance analyzed $\alpha=5 \%$, if the result of analyzed variance were significant, the data would analyze with Duncan multiple range test $\alpha=5 \%$. The result showed that application various Total-N start from 190-310 ppm nonsignificant affect the crop growth of Kailan Crop. The application of total N 190 ppm efficient to support Kailan crop growth.
\end{abstract}

Keywords: Total-N concentration., nutrient efficiency, electrical conductivity

\section{Introduction}

The development of hydroponic cultivation of vegetables and fruit trees today is inseparable from the limitations of productive land and the priority of productive land use for food crop cultivation. The implementation of hydroponic technology can be carried out on narrow land with limited water availability, but still, produce high [1]. Kailan crop is one of the leaf vegetable crops that have high economic value to be cultivated hydroponically. Kailan crops that are cultivated hydroponically have advantages, namely: relatively consistent growth, faster growth compared to cultivation on (conventional) land and cleaner harvest results. Increased production and productivity of hydroponic kailan crops are faced with constraints on the many hydroponic nutrients sold at different prices in the market [2]. Suitable hydroponic nutrition not only increases crop growth but also saves operational costs for purchasing hydroponic nutrients [3]. 
Some experts formulate hydroponic nutrition that is made independently or purchased on the market. Modifications or adjustments to formulas are needed to adapt to the characteristics of the tropical climate and kailan crops [4]. Nitrogen is a nutrient that is used as a basis in determining the proportion or concentration of other nutrients, especially macronutrients [5]. The ratio of elemental potassium $(\mathrm{K})$ to elements of nitrogen $(\mathrm{N})(\mathrm{K}: \mathrm{N})$ and elements of phosphorus $(\mathrm{P})$ to the element $\mathrm{N}(\mathrm{P}: \mathrm{N})$ shows that it affects the growth and yield of tomato crops [6], [7]. Crops harvested from leaves have a high tolerance for excessive $\mathrm{N}$ concentration [5]. High nitrate content and low vitamin $\mathrm{C}$ content in hydroponic crops is a challenge in improving the quality of leaf vegetable hydroponic products [8].

This study aims to determine the concentration of $\mathrm{N}$, which can support the growth of kailan crops, but from the price aspect, it is still economical [9].

\section{Methods}

This research was conducted in Ciparanje Jatinangor Sumedang greenhouse from September-October 2017. The equipment used in this study were: pH meter, EC meter, Thermohigrometer, measuring ruler, digital scales, water pumps, emitters and timers. The materials used are kailan or kale seeds, pipa PVC, PE hose $3 \mathrm{~mm}$, $5 \mathrm{Ca}\left(\mathrm{NO}_{3}\right)_{2} . \mathrm{NH}_{4} \mathrm{NO}_{3} .10 \mathrm{H}_{2} \mathrm{O}, \quad \mathrm{KNO}_{3}, \quad$ Fe-EDTA, $\left(\mathrm{NH}_{4}\right)_{2} \mathrm{SO}_{4}, \quad \mathrm{ZnSO} \mathrm{O}_{4} .7 \mathrm{H}_{2} \mathrm{O}, \quad \mathrm{KH}_{2} \mathrm{PO}_{4}$, $\mathrm{CuSO}_{4} .5 \mathrm{H}_{2} 0, \mathrm{H}_{3} \mathrm{BO}_{3},(\mathrm{Na}) 6 \mathrm{Mo}_{7} \mathrm{O}_{24} .4 \mathrm{H}_{2} \mathrm{O}, \mathrm{MgSO}_{4} .7 \mathrm{H}_{2} \mathrm{O}, \mathrm{K}_{2} \mathrm{SO}_{4}$.

The research method used was experimental research using a completely randomized design consisting of seven treatments of $\mathrm{N}$ concentration (ppm), namely: $\mathrm{A}=190, \mathrm{~B}=210, \mathrm{C}$ $=230, \mathrm{D}=250, \mathrm{E}=270, \mathrm{~F}=290$, and $\mathrm{G}=310$. Each treatment was repeated four times to obtain 28 experimental units. The growth parameters observed were: crop height, leaf area, crop dry weight, shoot-root ratio, and fresh weight of crops. The main supporting parameters of the observation are greenhouse temperature, humidity, and $\mathrm{pH}$ of nutrients. Variance analysis was used to analyze data from measurements of growth parameters at a real level of $5 \%$. If the results of the analysis of variance show a real effect, the data analysis is continued with a different test of Duncan's average value at the 5\% level. Data from the results of supporting observations were not analyzed for variance but were used as supporting data for growth parameter analysis.

The stages of the implementation of the study consisted of the nursery stage, making a drip irrigation installation, making hydroponic nutrition according to treatment, croping, maintenance and harvesting. Kailan/kale crops are sown using a seedling tray that has been filled with fuel husk. The nursery stage lasts 14 days after the seedling. The next process while waiting for the crops to be ready to move is to make a drip irrigation installation. This drip irrigation system consists of seven installations according to the number of treatments. Each installation consists of nutrient tanks, water pumps, nipples and emitters. The process of making hydroponic nutrition is carried out when the kailan crop is still sown so that when transcroping nutrients, it can be applied immediately. Making nutrition refers to Table 1 the ratio of macro elements to the concentration of $\mathrm{N}$ elements, namely: $\mathrm{P}: \mathrm{N}(0.3), \mathrm{K}: \mathrm{N}(1.3)$, Ca: $\mathrm{N}(0.7), \mathrm{Mg}: \mathrm{N}(0.25)$ and $\mathrm{S}: \mathrm{N}(0.4)$ while the micronutrient concentration in each treatment was made the same. 
Table 1. Hydroponics Nutrients Formula According to Concentration of Nitrogen

\begin{tabular}{ccccccccccccc}
\hline \multirow{2}{*}{ Treatments } & \multicolumn{11}{c}{ Concentrations (ppm) } \\
& $\mathrm{N}$ & $\mathrm{P}$ & $\mathrm{K}$ & $\mathrm{Ca}$ & $\mathrm{Mg}$ & $\mathrm{S}$ & $\mathrm{Fe}$ & $\mathrm{Mn}$ & $\mathrm{Cu}$ & $\mathrm{Zn}$ & $\mathrm{B}$ & Mo \\
\hline A & 190 & 57 & 247 & 133 & 48 & 86 & 5 & 2 & 0,1 & 0,3 & 0,7 & 0,05 \\
$\mathrm{~B}$ & 210 & 63 & 273 & 147 & 53 & 84 & 5 & 2 & 0,1 & 0,3 & 0,7 & 0,05 \\
$\mathrm{C}$ & 230 & 69 & 299 & 161 & 58 & 92 & 5 & 2 & 0,1 & 0,3 & 0,7 & 0,05 \\
D & 250 & 75 & 325 & 175 & 63 & 100 & 5 & 2 & 0,1 & 0,3 & 0,7 & 0,05 \\
E & 270 & 81 & 351 & 189 & 68 & 108 & 5 & 2 & 0,1 & 0,3 & 0,7 & 0,05 \\
F & 290 & 87 & 377 & 203 & 73 & 116 & 5 & 2 & 0,1 & 0,3 & 0,7 & 0,05 \\
G & 310 & 93 & 403 & 217 & 78 & 124 & 5 & 2 & 0,1 & 0,3 & 0,7 & 0,05 \\
& & P:N & K:N & Ca:N & Mg:N & S:N & & & & & & \\
Ratio & & 0,3 & 1,3 & 0,7 & 0,25 & 0,4 & & & & & & \\
\hline
\end{tabular}

Transcroping is carried out when the kailan seedlings are 14 days after seedling. The process of transcroping is done in the morning (start at six am in the morning). The croping medium used is husk charcoal, which is inserted into a polybag measuring $30 \times 30 \mathrm{~cm}$. The stages of maintenance include administering nutrients twice a day and controlling pest and disease attacks. Provision of nutrition and irrigation water is given simultaneously with the application of hydroponic nutrition with the value of Electrical Conductivity (EC) at the age of 1-14 HST $2.5 \mathrm{mS} \mathrm{cm}^{-1}$ and age 15-35 day after transcroping (DAT) $3 \mathrm{mS} \mathrm{cm}^{-1}$.

\section{Results and Discussions}

\subsection{Greenhouse Temperature and Humidity}

The daily temperature and humidity during the study were $28.6^{\circ} \mathrm{C}$ and $73.3 \%$ humidity. The average temperature condition of $28.6^{\circ} \mathrm{C}$ greenhouses is quite suitable to support the growth of kailan crops. The growth of kailan crops will reach the potential results when temperatures range from $16-22^{\circ} \mathrm{C}[10]$. Kailan crops are commodities that are harvested or consumed by their leaves so that their vegetative growth must be maximized to get a kailan crop that has large leaves and stems but still has a crunchy leaf and stem texture. Crops that are croped at temperatures higher than the ideal temperature will cause the transition of the vegetative phase to the generative phase to take place faster so that vegetative growth is inhibited [11]. Greenhouse temperatures that are too high also affect the efficiency of nutrient use due to increased evaporation and increased the temperature of nutrient solution. The high temperature of the solution can cause an increase in EC value drastically, which causes stress on crops and affects crop growth [3], [12]. 


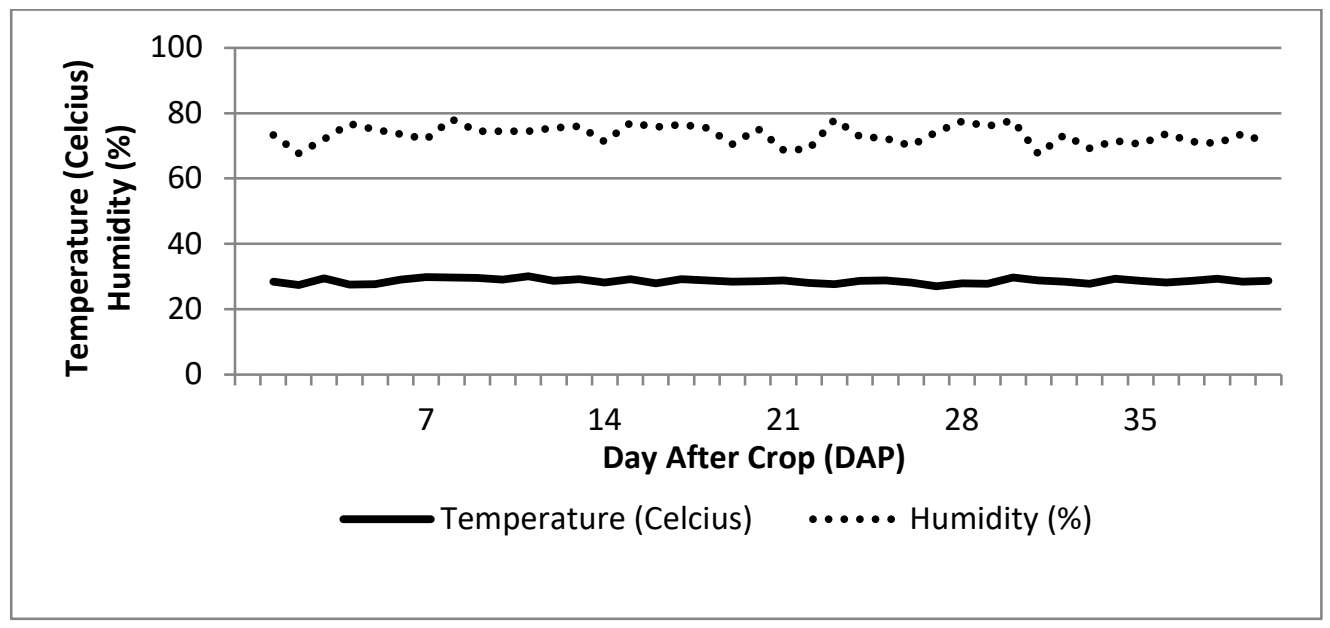

Figure 1. Graphic Temperature and Humidity of Greenhouse

\subsection{Electrical Conductivity and $\mathrm{pH}$ Value}

The $\mathrm{pH}$ value of the solution averaged 6.3 in hydroponic cultivation exceeding the recommended recommendation for $\mathrm{pH}$ of nutrient solution, ie 5.6-6.2 [13]. At too high a pH it causes the availability of microelements and microelement uptake to be inhibited on the contrary at too low a pH causing an increase in availability and absorption of microelements so that they are toxic to crops. Nutrient solutions given to crops have different EC values for each change in crop age, namely: age 1-14 days after transcroping (DAT) $\left(2.5 \mathrm{mS} \mathrm{cm}^{-1}\right)$ and 15-35 DAT $\left(3 \mathrm{mS} \mathrm{cm}^{-1}\right)$.

\subsection{Crop Height $(\mathrm{cm})$}

The results of data analysis showed that the application of total nitrogen from 190 to 310 ppm was not significantly different from the increase in crop height (Figure 1). Growth in crop height is a complex growth parameter that is influenced by external factors such as sunlight intensity, water availability and nutrients. Kailan crops that are fulfilled the growth requirements will show normal high growth not experiencing excessive height or etiolation or stunting high growth. The growth of cauliflower in this study from 190-310 total nitrogen showed etiolation symptoms. In conditions of sunlight met and nutrients fulfilled, the kailan crop produces a height of $18.20 \mathrm{~cm}$ compared to crops given liquid organic fertilizer to produce a height of $23.50 \mathrm{~cm} \mathrm{[14].} \mathrm{In} \mathrm{this} \mathrm{study,} \mathrm{the} \mathrm{application} \mathrm{of} \mathrm{total} \mathrm{nitrogen} \mathrm{210-250} \mathrm{has}$ the potential to reduce etiolation symptoms when compared with the total nitrogen application of $190 \mathrm{ppm}$.

3.4 Crop Leaf Area, Dry Weight and Fresh Weight

The results of the analysis of variance show that the effect of the application of total nitrogen on the parameters of the leaf area, the dry weight and crop fresh weight crop is not significantly different. In the application of total nitrogen $190 \mathrm{ppm}$, the formation of leaf area, 
dry weight and fresh weight of crops were more efficient compared to the application of total nitrogen $290 \mathrm{ppm}$. Hydroponic fertilizer formulations use total nitrogen concentrations as the basis for other macro-elements assignments so that lower total nitrogen applications can save fertilizer costs. The overall results of the study indicate that the results of crop growth in 190310 can be used as a reference for making hydroponic fertilizers in kailan crops (Table 2). However, according to the research objectives, the most efficient total nitrogen is the lowest total nitrogen concentration with high crop growth. The results of this study confirm previous studies that affecting crop growth is more to electrical conductivity (EC) and acidity (pH) compared to nutrient solutions [15].

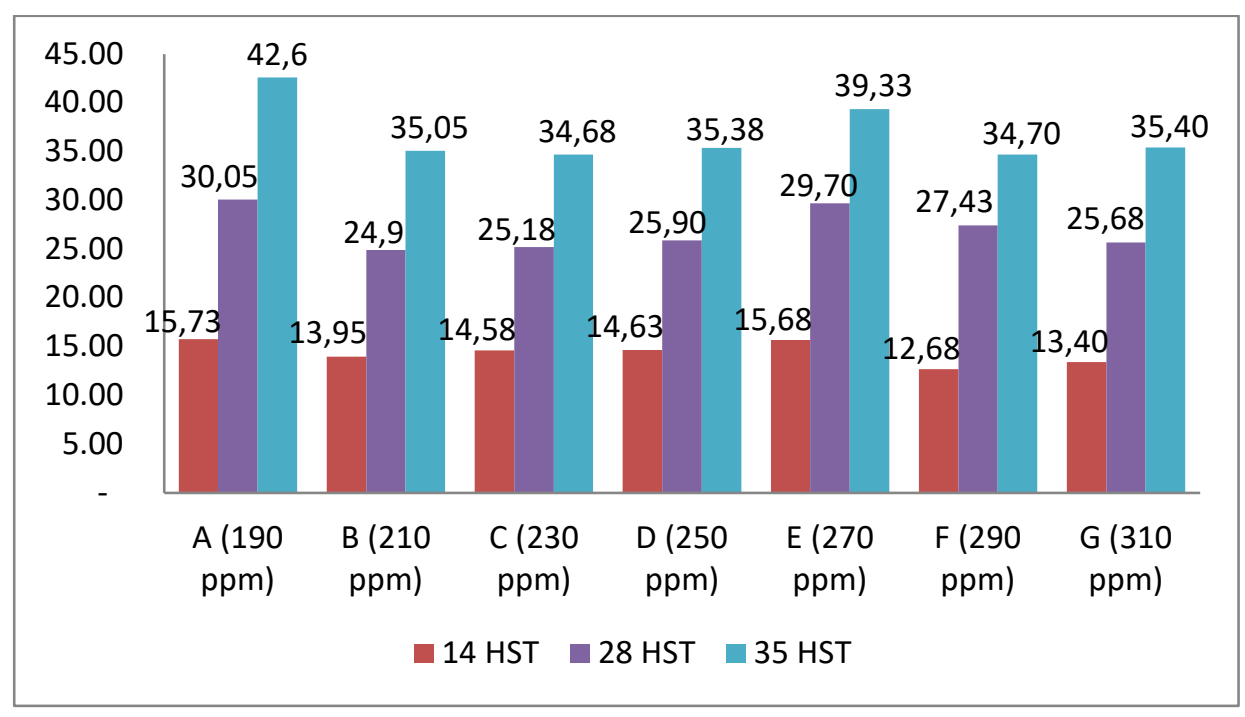

Figure 2. Graph of Crop Height (cm)

Table 2. Average of crop Leaf Area, crop dry weight and Fresh Weight

\begin{tabular}{ccrc}
\hline Treatments Total $-\mathrm{N}(\mathrm{ppm})$ & Leaf Area $(\mathrm{cm} 2)$ & Dry Weight $(\mathrm{g})$ & Fresh Weight $(\mathrm{g})$ \\
\hline $\mathrm{A}=190$ & 2416.00 & 16.80 & 151.30 \\
$\mathrm{~B}=210$ & 1250.00 & 11.92 & 117.58 \\
$\mathrm{C}=230$ & 1312.20 & 10.03 & 103.28 \\
$\mathrm{D}=250$ & 1566.00 & 11.97 & 140.53 \\
$\mathrm{E}=270$ & 1585.20 & 15.15 & 152.33 \\
$\mathrm{~F}=290$ & 2623.30 & 12.75 & 155.30 \\
$\mathrm{G}=310$ & 1880.00 & 13.02 & 134.20 \\
\hline
\end{tabular}




\section{Conclusion}

The result showed that application various total-N in the range of $190-310 \mathrm{ppm}$ showed non significant effect on the growth of kailan crop.

\section{References}

[1] L. I. Trejo-Téllez and F. C. Gómez-Merino, "Nutrient Solutions for Hydroponic Systems," Intech open, vol. 2, p. 64, 2015.

[2] B. Frasetya, K. Harisman, and A. Rohim, "Evaluasi Nutrisi Hidroponik Alternatif terhadap Pertumbuhan dan Hasil Mentimun Jepang Varietas Roberto pada Hidroponik Irigasi Tetes Infus," in Prosiding Seminar Nasional Fakultas Pertanian UNS, 2018, vol. 2, no. 1, pp. 230-238.

[3] B. Frasetya, A. Taofik, and R. K. Firdaus, "Evaluasi Variasi Nilai Electrical Conductivity Terhadap Pertumbuhan Tanaman Selada ( Lactuca sativa L .) pada Sistem NFT," J. Agro, vol. 5, no. 2, pp. 95-102, 2018

[4] B. Frasetya, K. Harisman, A. Rohim, and C. Hidayat, "Evaluasi Nutrisi Hidroponik Alternatif terhadap Pertumbuhan dan Hasil Mentimun Jepang Varietas Roberto pada Hidroponik Irigasi Tetes Infus," in Peran Keanekaragaman Hayati untuk Mendukung Indonesia sebagai Lumbung Pangan Dunia, 2018, vol. 2, no. 1.

[5] H. M. Resh, Hydroponic Food Production, 7th ed. New York: CRS Press, 2013.

[6] H. Kaur, S. Bedi, V. P. Sethi, and A. S. Dhatt, "Effects of substrate hydroponic systems and different $\mathrm{N}$ and $\mathrm{K}$ ratios on yield and quality of tomato fruit," J. Crop Nutr., vol. 41, no. 12, pp. 1547$1554,2018$.

[7] C. Hidayat, B. Frasetya, and I. N. Syamsudin, "Adjustment of Phosphorus Concentration to Increase Growth and Yield of Cherry Tomato Using Hydroponic Drip System Pengaturan Konsentrasi Fosfor untuk Meningkatkan Pertumbuhan dan Hasil Tanaman Tomat Cherry pada Sistem Hidroponik Irigasi Tetes," J. Agro, vol. 5, no. 2, pp. 140-147, 2018.

[8] W. L. Zhou, W. K. Liu, and Q. C. Yang, "Quality changes in hydroponic lettuce grown under pre-harvest short-duration continuous light of different intensities," J. Hortic. Sci. Biotechnol., vol. 87, no. 5, pp. 429-434, 2012.

[9] B. F. T. Qurrohman, Formulasi Nutrisi Hidroponik AB Mix dengan Aplikasi MS Excel dan Hydrobuddy. Yogyakarta: Cropaxia, 2017.

[10] D. Djaenudin, Marwan H, and Subagjo H, Petunjuk Teknis Evaluasi Lahan untuk Komoditas Pertanian. Bogor: Balai Besar Litbang Sumberdaya Lahan Pertanian, Badan Litbang Pertanian, 2011.

[11] S. R. Adams, K. E. Cockshull, and C. R. J. Cave, "Effect of temperature on the growth and development of tomato fruits," Ann. Bot., vol. 88, no. 5, pp. 869-877, 2001.

[12] D. S. Domingues, H. W. Takahashi, C. A. P. Camara, and S. L. Nixdorf, "Automated system developed to control $\mathrm{pH}$ and concentration of nutrient solution evaluated in hydroponic lettuce production," Comput. Electron. Agric., vol. 84, pp. 53-61, 2012.

[13] Grace, "Understanding Water Quality, Water EC , and pH," California, 2016.

[14] D. K. Sari, M. D. Duaja, and Neliyati, "Pengaruh Perbedaan Formula Pupuk pada Pertumbuhan dan Hasil Kaian (Brassica oleracea)," Biocropae, vol. 3, no. 1, pp. 741-753, 2017.

[15] S. E. Wortman, "Crop physiological response to nutrient solution electrical conductivity and pH in an ebb-and-flow hydroponic system," Sci. Hortic. (Amsterdam)., vol. 194, pp. 34-42, 2015. 